\title{
Manifesto on small airway involvement and management in asthma and chronic obstructive pulmonary disease: an Interasma (Global Asthma Association - GAA) and World Allergy Organization (WAO) document endorsed by Allergic Rhinitis and its Impact on Asthma (ARIA) and Global Allergy and Asthma European Network (GA $\left.{ }^{2} L E N\right)$
}

F. Braido ${ }^{1}$, N. Scichilone ${ }^{2}$, F. Lavorini ${ }^{3}$, O. S. Usmani ${ }^{4}$, L. Dubuske ${ }^{5}$, L. P. Boulet ${ }^{6}$, R. Mosges$^{7}$, C. Nunes $^{8}$, M. Sánchez-Borges ${ }^{9,10}$, I. J. Ansotegui ${ }^{11}$, M. Ebisawa ${ }^{12}$, F. Levi-Schaffer ${ }^{13}$, L. J Rosenwasser ${ }^{14}$, J. Bousquet ${ }^{15}$,

T. Zuberbier ${ }^{16}$, G. Walter Canonica ${ }^{1 *}$, for the Interasma Executive Board, WAO Board of Directors, ARIA and GA ${ }^{2}$ LEN

\begin{abstract}
Evidence that enables us to identify, assess, and access the small airways in asthma and chronic obstructive pulmonary disease (COPD) has led INTERASMA (Global Asthma Association) and WAO to take a position on the role of the small airways in these diseases.

Starting from an extensive literature review, both organizations developed, discussed, and approved the manifesto, which was subsequently approved and endorsed by the chairs of ARIA and GA²LEN. The manifesto describes the evidence gathered to date and defines and proposes issues on small airway involvement and management in asthma and COPD with the aim of challenging assumptions, fostering commitment, and bringing about change.

The small airways (defined as those with an internal diameter $<2 \mathrm{~mm}$ ) are involved in the pathogenesis of asthma and COPD and are the major determinant of airflow obstruction in these diseases. Various tests are available for the assessment of the small airways, and their results must be integrated to confirm a diagnosis of small airway dysfunction.

In asthma and COPD, the small airways play a key role in attempts to achieve disease control and better outcomes. Small-particle inhaled formulations (defined as those that, owing to their size [usually $<2 \mu \mathrm{m}$ ], ensure more extensive deposition in the lung periphery than large molecules) have proved beneficial in patients with asthma and COPD, (Continued on next page)
\end{abstract}

\footnotetext{
* Correspondence: canonica@unige.it

${ }^{1}$ Allergy and Respiratory Diseases Department DIMI, University of Genoa, IRCCS

AOU San Martino-IST, Genoa, Italy

Full list of author information is available at the end of the article
} 


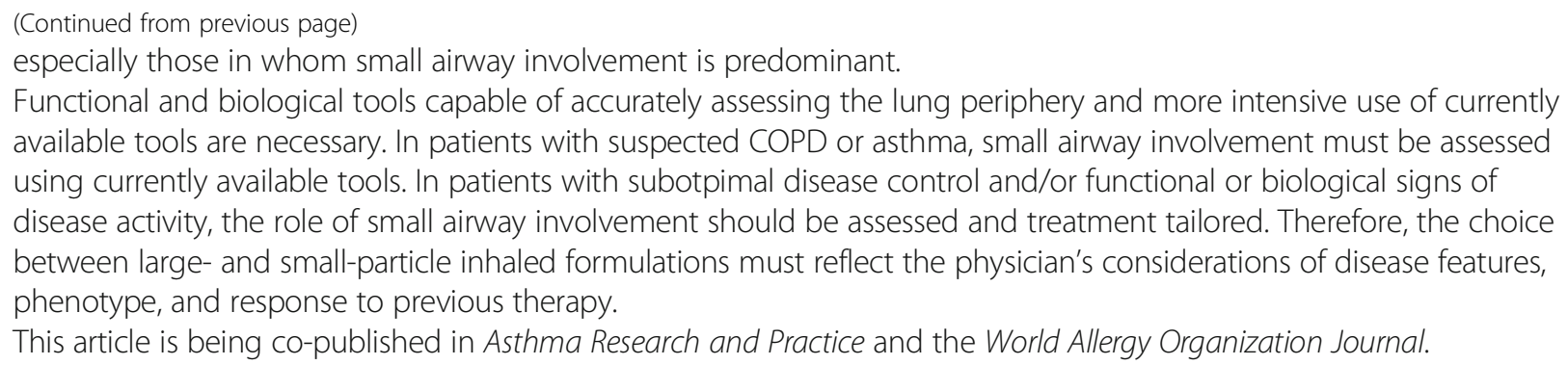

\section{Background}

A manifesto, from the Latin "manifestum" (meaning clear or evident), is a declaration of the beliefs, opinions, motives, and intentions of the issuer, be it an individual or a group. It is normally based on previously published opinion or public consensus and attempts to promote new ideas with prescriptive notions. In the context of health care, a manifesto describes confirmed evidence, actions required, and investigations necessary and is issued by a group of experts or a scientific organization on a specific topic. By leading people to evaluate the gap between these principles and their current reality, the manifesto challenges assumptions, fosters commitment, and provokes change.

The involvement of the small airways of the lung ("silent zone") in the pathogenesis of asthma and chronic obstructive pulmonary disease (COPD) is currently the object of much research and debate, and the ability to identify, assess, and access the small airways enables us to take a position on this timely issue in the light of available evidence.

We performed a PubMed search using the $\mathrm{MeSH}$ terms "small airway" and "small particle" within the last three years (January 2013 to January 2016). We also used the key words "large", "fine", "small", "respirable", "extrafine", "extra-small particle", together with the MeSh terms "asthma/COPD", which were limited to clinical trials without time limits. All selected papers were initially evaluated by a panel of experts to assess their eligibility in contributing to the statements of the manifesto. In February 2016, the draft of the manifesto was circulated among the Board of Officers of Interasma (Global Asthma Association) and the WAO Board of Directors, who appraised, discussed, and approved the final version. The final version of the Manifesto was approved and endorsed by the chairs of ARIA $^{\S}$ and GA $^{2}$ LEN $^{\wedge}$.

\section{We define}

Small airways as those with an internal diameter $<2 \mu \mathrm{m}$ [1].

Drug particles smaller than $5 \mu \mathrm{m}$ are called "large particles"; "small particles" are defined as particles whose size (usually $<2 \mu \mathrm{m}$ ) enables them to be depositied in the lung periphery in greater amounts than large molecules $[2-6]$.

\section{We know}

That while the small airways contribute little to total airway resistance in healthy lungs, in asthma and in COPD they are the major determinant of airflow obstruction $[7,8]$.

It has been estimated that $75 \%$ of the small airways must be obstructed before changes can be detected using routine pulmonary function tests (e.g. forced expiratory volume in 1 second $\left.\left[\mathrm{FEV}_{1}\right]\right)$. [9].

Various tests are available for the assessment of small airways. The detection of an abnormal forced expiratory flow $\left(\mathrm{FEF}_{25-75}\right)$ should be supported by other pulmonary function tests (impulse oscillometry, whole-body plethysmography, exhaled-breath nitric oxide, and single-breath and multiple-breath nitrogen washout) to confirm a diagnosis of small airway dysfunction [4, 10-12].

\section{Asthma}

The small airways play a role in the pathobiology of asthma and, although they are involved in half of all cases of asthma, they can have a distinct role in specific disease phenotypes [13-17].

Inflammatory changes involving the small airways influence the severity of asthma [18-23].

Functional alterations of the small airways are also associated with the severity of asthma [24-32].

The role of the small airways in asthma is increasingly recognized as a potential target in optimal control of the disease [33-36].

The development of small-particle inhaled formulations enables the drug to reach both the large and the small airways [37-39].

Small-particle aerosols have been shown to be as efficacious as large-particle aerosols in randomized controlled trials; however, real-life studies have shown that smaller particles are more efficacious and improve asthma control and quality of life compared with large particles; in addition, they do so with a marked reduction in the daily dose of inhaled corticosteroids (ICS) [37, 40-75].

\section{COPD}

COPD is characterized by a mixture of small airway impairment (obstructive bronchitis/bronchiolitis) and parenchymal lung tissue destruction (emphysema). The 
progression of COPD is strongly associated with small airway wall thickening as a result of lung repair or remodelling [76-79].

Small airway disease in COPD can be identified by pulmonary function testing, multiple nitrogen breath washout testing, indirectly through high-resolution chest computed tomography (CT) imaging or inert-gas MRI imaging, or directly using microCT of resected lung tissue [80, 81].

In COPD, air trapping and functional small airway impairment are associated with inflammation of the peripheral airways [82-84].

The effects of significantly low-dose small-particle ICS on exacerbation rates are similar to those of larger-particle ICS at higher doses. Initiation of small-particle ICS is associated with a greater likelihood of stable treatment [85-87].

The combination of small-particle ICS and long-acting beta-agonists has been effective in reducing air trapping and improving health-related quality of life and dyspnea in COPD patients with lung hyperinflation [88-94].

\section{We state}

That small airways play a key role in the pathogenesis of asthma and COPD.

In asthma and in COPD, the small airways can be targeted to ensure disease control and better outcomes.

Small-particle inhaled formulations are beneficial in patients with asthma and COPD, especially those with predominant small airway involvement.

\section{We advocate}

The need for functional and biological tools that can accurately assess the lung periphery and a more intensive use of currently available tools for improved patient phenotyping.

The lack of consensus on the terminology used to describe small drug particles necessitates a clear nomenclature to ensure that uniform terminology is used by professionals.

Research should aim to identify a specific "small airway phenotype" so that uncontrolled disease can be treated appropriately.

\section{We propose}

That in patients with suspected COPD or asthma, small airway involvement should be taken into consideration and explored using currently available tools.

In patients with suboptimal disease control and/or functional or biological signs of disease activity, the role of the small airways should be assessed to provide tailored treatment.

The choice of large-particle inhaled formulations over small-particle inhaled formulations must reflect the physician's considerations of disease features, phenotype, and response to previous therapy.

\section{Abbreviations}

ARIA: Allergic rhinitis and its impact on asthma; COPD: Chronic obstructive pulmonary disease; CT: Computed tomography; FEF 25-75 \%: Forced expiratory flow at 25-75\% of forced vital capacity; FEV1: Forced expiratory volume in 1 second; GA2LEN: Global Allergy And Asthma European Network; ICS: Inhaled corticosteroid; MRI: Magnetic resonance imaging; WAO: World Allergy Organization

\section{Acknowledgements}

We aknowledge: Interasma, WAO, ARIA, GA2LEN. Thomas O'Boyle for linguistic revision.

\section{For the Interasma Executive Board}

Cruz A: ProAR - Núcleo de Excelência em Asma, Universidade Federal da Bahia, Salvador, Brazi.

Yanez A: Division of Allergy and Immunology, Servicio de Alergia e Inmunología Clínica, Hospital Aeronáutico Central, Buenos Aires, Argentina. Yorgancioglu A: Pulmonary Diseases Department, Celal Bayar University School of Medicine, Manisa, Turkey.

Deleanu D: Department of Allergology, Iuliu Hațieganu University of Medicine and Pharmacy, Cluj-Napoca, Romania.

Rodrigo G: Departamento de Emergencia, Hospital Central de las Fuerzas Armadas, Montevideo, Uruguay.

Berstein J: Department of Internal Medicine, University of Cincinnati, Cincinnati, OH, USA

Ohta K: Respiratory Center, National Hospital Organization Tokyo National Hospital, Tokyo, Japan.

Vichyanond P: Division of Allergy and Immunology, Department of Pediatrics, Faculty of Medicine Siriraj Hospital Mahidol University, Bangkok, Thailand. Gonzales Diaz S: Servicio de Alergia e Immunologia Clinica, Hospital Universitario, Monterrey, Nuevo Leon, Mexico.

Nakajima S: Internal Medicine, Jobu Hospital for Respiratory Disease, Maebashi, Gunma, Japan.

Slavyanskaya T: Peoples Friendship University of Russia, Moscow, Russia. Institute of Immunophysiology, Moscow, Russia. Vladivostok State Medical University, Vladivostok, Russia.

Fink-Wargner A: Global Allergy and Asthma Patient Platform GAAPP, Wien, Austria.

Baez Loyola C: Médica Sur, Puente de Piedra, Tlalpan, Mexico.

Ryan D: University of Edinburgh, Edinburgh, UK.

Passalacqua G: Allergy and Respiratory Diseases Department DIMI, University of Genoa, IRCCS AOU San Martino-IST, Genoa, Italy.

Celedon J: Department of Pediatrics, Division of Pulmonary Medicine, Allergy, and Immunology, Children's Hospital of Pittsburgh of UPMC, Pittsburgh, USA Invancevich JC: Division of Immunology, Medical School, Universidad del

Salvador, Buenos Aires, Argentina. Clinica Santa Isabel, Buenos Aires,

Argentina.

Dobashi K: Graduate School of Health Sciences, Gunma University, Maebashi, Japan

Zernotti M: Universitad Catolica de Cordoba, Córdoba, Argentina.

\section{WAO Board of Directors}

Sanchez-Borges M: Centro Medico Docente La Trinidad, Caracas, Venezuela. Clinica El Avila, Caracas, Venezuela.

Ansotegui IJ: Department of Allergy and Immunology, Hospital Quirón

Bizkaia, Carretera Leioa-Inbe, Erandio, Bilbao, Spain.

Ebisawa M: Department of Allergy, Clinical Research Center for Allergy \& Rheumatology, Sagamihara National Hospital, Sagamihara, Kanagawa, Japan. Levi-Schaffer F: Department of Pharmacology and Experimental Therapeutics, Institute for Drug Research, School of Pharmacy, Faculty of Medicine, The Hebrew University of Jerusalem, Jerusalem, Israel.

Rosenwasser LJ: University of Missouri - Kansas City, School of Medicine, Kansas City, USA.

Akdis M: Swiss Institute of Allergy and Asthma Research, University of Zurich, Zurich, Switzerland. Christine Kühne-Center for Allergy Research and Education, Davos, Switzerland.

Benjaponpitak S: Division of Pediatric Allergy/Immunology/ Rheumatology, Department of Pediatrics, Ramathibodi Hospital, Mahidol University, Bangkok, Thailand.

Bonini S: European Medicines Agency, London, UK. Second University of Naples and IFT-CNR, Rome, Italy. 
Burks W: Department of Pediatrics, University of North Carolina at Chapel Hill, Chapel Hill, NC, USA

Caraballo L: Institute for Immunological Research, University of Cartagena, Cartagena, Colombia. Foundation for the Development of Medical and Biological Sciences (Fundemeb), Cartagena, Colombia.

Awad El-Sayed Z: Suez Canal University, Ismailiya, Egypt.

Fineman S: Atlanta Allergy and Asthma Clinic and Department of Pediatrics, Emory University School of Medicine, Atlanta, USA.

Greenberger P: Division of Allergy-Immunology, Department of Medicine, Northwestern University Feinberg School of Medicine, Chicago, USA.

Hossny E: Pediatric Allergy and Immunology, Ain Shams University, Cairo, Egypt. Ortega-Martell JA: Institute of Health Sciences of the Autonomous University of the State of Hidalgo, Pachuca, Mexico.

Pawankar R: Department of Pediatrics, Nippon Medical School, Tokyo, Japan. Saito H: Department of Otorhinolaryngology and Head and Neck Surgery, Akita University Graduate School of Medicine, Akita, Japan.

Tang M: Department of Allergy and Immune Disorders, Murdoch Children's Research Institute, Parkville, Melbourne, Australia.

Zernotti M: Universitad Catolica de Cordoba, Córdoba, Argentina.

Zhang L: Department of Respiration Medicine, West China Hospital, Sichuan University, Chengdu, China.

\section{ARIA}

Bousquet J: Service des Maladies Respiratoires, Hopital Arnaud de Villeneuve, Montpellier, France.

\section{GA ${ }^{2} L E N$}

Zuberbier T: Department of Dermatology and Allergy, Charité-Universitätsmedizin Berlin, Berlin, Germany.

\section{Funding}

No funding.

\section{Availability of data and materials} Not applicable.

\section{Authors' contributions}

$\mathrm{BF}, \mathrm{SN}, \mathrm{LF}, \mathrm{UOS}$, CGW: conception and design, acquisition of data, drafting the manuscript. CA, YA, YA, DD, RG, BJ, OK, VP, PR, GDS, NS, ST, F-WA, BLC, $R D, P G, C J, I J C, D K, Z M, A M, B S, B S, B W, C L$, AE-SZ, FS, GP, HE, O-MJA, SH, $T M, Z L$ : critical revision of the draft for important intellectual content. DL, BLP, $M R, N C, S B M, A I J, E M, L-S F, R \sqcup, B J, Z T \wedge, C G W 1$ : critical revision of the draft for important intellectual content; final approval of the version to be published. All authors read and approved the final manuscript.

\section{Competing interests}

The authors declare that they have no competing interests.

\section{Consent for publication}

Not applicable.

\section{Ethics approval and consent to participate}

Not applicable.

\section{Declaration}

This article is being co-published in Asthma Research and Practice and the World Allergy Organization Journal.

\footnotetext{
Author details

'Allergy and Respiratory Diseases Department DIMI, University of Genoa, IRCCS AOU San Martino-IST, Genoa, Italy. ${ }^{2}$ Dipartimento Biomedico di Medicina Interna e Specialistica, University of Palermo, Palermo, Italy. ${ }^{3}$ Department of Experimental and Clinical Medicine, University of Florence, Florence, Italy. ${ }^{4}$ Airway Disease Section, National Heart and Lung Institute, Imperial College London, Royal Brompton Hospital, London, UK. ${ }^{5}$ Immunology Research Institute of New England, Harvard, USA. ${ }^{6}$ Centre de recherche de I'Institut universitaire de cardiologie et de pneumologie de Québec, Québec, Canada. Institute of Medical Statistics, Informatics and Epidemiology, University Hospital of Cologne, Cologne, Germany. ${ }^{8}$ Centro de ImmunoAlergologia de Algarve, Porto, Portugal. ${ }^{9}$ Centro Medico Docente La Trinidad, Caracas, Venezuela. ${ }^{10} \mathrm{Clinica}$ El Avila, Caracas, Venezuela. "'Department of Allergy and Immunology, Hospital Quirón
}

Bizkaia, Carretera Leioa-Inbe, Erandio, Bilbao, Spain. ${ }^{12}$ Department of Allergy, Clinical Research Center for Allergy \& Rheumatology, Sagamihara National Hospital, Sagamihara, Kanagawa, Japan. ${ }^{13}$ Department of Pharmacology and Experimental Therapeutics, Institute for Drug Research, School of Pharmacy, Faculty of Medicine, The Hebrew University of Jerusalem, Jerusalem, Israel. ${ }^{14}$ University of Missouri - Kansas City, School of Medicine, Kansas City, Missouri, USA. ${ }^{15}$ Service des Maladies Respiratoires, Hopital Arnaud de Villeneuve, Montpellier, France. ${ }^{16}$ Department of Dermatology and Allergy,

Charité-Universitätsmedizin Berlin, Berlin, Germany.

Received: 3 June 2016 Accepted: 22 August 2016 Published online: 19 September 2016

\section{References}

1. Burgel PR, De Blic J, Chanez P, Delacourt C, Devillier P, Didier A, Dubus JC, Frachon I, Garcia G, Humbert M, Laurent F, Louis R, Magnan A, Mahut B, Perez T, Roche N, Tillie-Leblond I, Tunon De Lara M, Dusser D. Update on the roles of distal airways in asthma. Eur Respir Rev. 2009;18:80-95.

2. Heyder J, Svartengren MU. Basic Principles of particle behavior in the human respiratory tract. In: Bisgaard H, O'Callaghan C, Smaldone GC, editors. Drug delivery to the lungs. Lung biology in health and disease. New York: Marcel Dekker; 2002. 162:pp. 21-45.

3. Laube BL, Janssens HM, de Jongh FH, Devadason SG, Dhand R, Diot P, Everard ML, Horvath I, Navalesi P, Voshaar T, Chrystyn H, European Respiratory Society; International Society for Aerosols in Medicine. What the pulmonary specialist should know about the new inhalation therapies. Eur Respir J. 2011;37(6):1308-31.

4. Lipworth B, Manoharan A, Anderson W. Unlocking the quiet zone: the small airway asthma phenotype. Lancet Respir Med. 2014;2(6):497-506.

5. Dolovich MB, Mitchell JP. Canadian Standards Association standard CAN/CSA/ Z264.1-02: 2002: a new voluntary standard for spacers and holding chambers used with pressurized metered-dose inhalers. Can Respir J. 2004;11(7):489-95.

6. Ong HX, Traini D, Loo CY, Sarkissian L, Lauretani G, Scalia S, Young PM. Is the cellular uptake of respiratory aerosols delivered from different devices equivalent? Eur J Pharm Biopharm. 2015:93:320-7.

7. Hogg JC. Pathophysiology of airflow limitation in chronic obstructive pulmonary disease. Lancet. 2004;364:709-72.

8. Yanai M, Sekizawa K, Ohrui T, Sasaki H, Takishima T. Site of airway obstruction in pulmonary disease: direct measurement of intrabronchial pressure. J Appl Physiol. 1992;72(3):1016-23.

9. Cosio M, Ghezzo H, Hogg JC, Corbin R, Loveland M, Dosman J, Macklem PT. The relations between structural changes in small airways and pulmonaryfunction tests. N Engl J Med. 1978;298:1277-81.

10. McNulty W, Usmani OS. Techniques of assessing small airways dysfunction. Eur Clin Respir J. 2014;17:1.

11. Ciprandi G, Cirillo I, Pasotti F, Ricciardolo FL. FEF25-75: a marker for small airways and asthma control. Ann Allergy Asthma Immunol. 2013;111(3):233.

12. Konstantinos Katsoulis $\mathrm{K}$, Kostikas $\mathrm{K}$, Kontakiotis $T$. Techniques for assessing small airways function: Possible applications in asthma and COPD. Respir Med. 2013 Jun 10. S0954-6111(13)00175-3.

13. Bonini M, Usmani OS. The role of the small airways in the pathophysiology of asthma and chronic obstructive pulmonary disease. Ther Adv Respir Dis. 2015;9(6):281-93.

14. Farah CS, Keulers LA, Hardaker KM, Peters MJ, Berend N, Postma DS, Salome CM, King GG. Association between peripheral airway function and neutrophilic inflammation in asthma. Respirology. 2015;20(6):975-81.

15. Contoli M, Santus P, Papi A. Small airway disease in asthma: pathophysiological and diagnostic considerations. Curr Opin Pulm Med. 2015;21(1):68-73.

16. Singer $F$, Abbas $C$, Yammine $S$, Casaulta $C$, Frey U, Latzin $P$. Abnormal small airways function in children with mild asthma. Chest. 2014;145(3):492-9.

17. Ivancsó I, Böcskei R, Müller V, Tamási L. Extrafine inhaled corticosteroid therapy in the control of asthma. J Asthma Allergy. 2013;6:69-80.

18. Kraft M, Pak J, Martin RJ, Kaminsky D, Irvin CG. Distal lung dysfunction at night in nocturnal asthma. Am J Respir Crit Care Med. 2001;163(7):1551-6.

19. Berry M, Hargadon B, Morgan A, Shelley M, Richter J, Shaw D, Green RH, Brightling C, Wardlaw AJ, Pavord ID. Alveolar nitric oxide in adults with asthma: evidence of distal lung inflammation in refractory asthma. Eur Respir J. 2005;25(6):986-91.

20. Scichilone N, Battaglia S, Taormina S, Modica V, Pozzecco E, Bellia V. Alveolar nitric oxide and asthma control in mild untreated asthma. J Allergy Clin Immunol. 2013;131(6):1513-7. 
21. Trischler J, Müller CM, Könitzer S, Prell E, Korten I, Unverzagt S, Lex C. Elevated exhaled leukotriene $B_{4}$ in the small airway compartment in children with asthma. Ann Allergy Asthma Immunol. 2015;114(2):111-6.

22. Perez T, Chanez P, Dusser D, Devillier P. Small airway impairment in moderate to severe asthmatics without significant proximal airway obstruction. Respir Med. 2013;107(11):1667-74.

23. Chen X, Wang K, Jiang M, Nong GM. Leukotriene receptor antagonists for small-airway abnormalities in asthmatics: a systematic review and metaanalysis. J Asthma. 2013;50(7):695-704.

24. Takeda T, Oga T, Niimi A, Matsumoto H, Ito I, Yamaguchi M, Matsuoka H, Jinnai M, Otsuka K, Oguma T, Nakaji H, Chin K, Mishima M. Relationship between small airway function and health status, dyspnea and disease control in asthma. Respiration. 2010;80(2):120-6.

25. Bourdin A, Paganin F, Préfaut C, Kieseler D, Godard P, Chanez P. Nitrogen washout slope in poorly controlled asthma. Allergy. 2006;61(1):85-9.

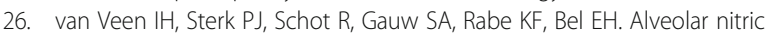
oxide versus measures of peripheral airway dysfunction in severe asthma. Eur Respir J. 2006;27(5):951-6.

27. Alfieri V, Aiello M, Pisi R, Tzani P, Mariani E, Marangio E, Olivieri D, Nicolini G, Chetta A. Small airway dysfunction is associated to excessive bronchoconstriction in asthmatic patients. Respir Res. 2014;15:86.

28. Kalliola S, Malmberg LP, Pelkonen AS, Mäkelä MJ. Aberrant small airways function relates to asthma severity in young children. Respir Med. 2016;111:16-20.

29. van der Wiel E, Postma DS, van der Molen T, Schiphof-Godart L, Ten Hacken $\mathrm{NH}$, van den Berge M. Effects of small airway dysfunction on the clinical expression of asthma: a focus on asthma symptoms and bronchial hyperresponsiveness. Allergy. 2014;69(12):1681-8.

30. Sposato B, Scalese M, Migliorini MG, Di Tomassi M, Scala R. Small airway Impairment and bronchial hyperresponsiveness in asthma onset. Allergy Asthma Immunol Res. 2014;6(3):242-51.

31. Boudewijn IM, Telenga ED, van der Wiel E, van der Molen T, Schiphof $L$, Ten Hacken NH, Postma DS, van den Berge M. Less small airway dysfunction in asymptomatic bronchial hyperresponsiveness than in asthma. Allergy. 2013; 68(11):1419-26.

32. de Telenga ED, van den Berge $M$, Ten Hacken NH, Riemersma RA, van der Molen T, Postma DS. Small airways in asthma: their independent contribution to the severity of hyperresponsiveness. Eur Respir J. 2013;41(3):752-4.

33. Contoli M, Bousquet J, Fabbri LM, Magnussen H, Rabe KF, Siafakas NM Hamid Q, Kraft M. The small airways and distal lung compartment in asthma and COPD: a time for reappraisal. Allergy. 2010;65(2):141-51.

34. Tulic MK, Christodoulopoulos P, Hamid Q. Small airway inflammation in asthma. Respir Res. 2001;2(6):333-9.

35. Hodgson D, Anderson J, Reynolds C, Meakin G, Bailey H, Pavord I, Shaw D, Harrison T. A randomised controlled trial of small particle inhaled steroids in refractory eosinophilic asthma (SPIRA). Thorax. 2015;70(6):559-65.

36. Bulac S, Cimrin A, Ellidokuz H. The effect of beclometasone dipropionate/ formoterol extra-fine fixed combination on the peripheral airway inflammation in controlled asthma. J Aerosol Med Pulm Drug Deliv. 2015; 28(2):82-7.

37. Usmani OS. Treating the small airways. Respiration. 2012;84(6):441-53.

38. van den Berge $\mathrm{M}$, ten Hacken $\mathrm{NH}$, van der Wiel E, Postma DS. Treatment of the bronchial tree from beginning to end: targeting small airway inflammation in asthma. Allergy. 2013;68(1):16-26.

39. De Backer W, Devolder A, Poli G, Acerbi D, Monno R, Herpich C, Sommerer K, Meyer T, Mariotti F. Lung deposition of BDP/formoterol HFA pMDI in healthy volunteers, asthmatic, and COPD patients. J Aerosol Med Pulm Drug Deliv. 2010;23(3):137-48.

40. Usmani OS, Biddiscombe MF, Barnes PJ. Regional lung deposition and bronchodilator response as a function of beta2-agonist particle size. Am J Respir Crit Care Med. 2005;172(12):1497-504.

41. Fabbri LM, Nicolini G, Olivieri D, Papi A. Inhaled beclometasone dipropionate/ formoterol extra-fine fixed inhaled beclometasone dipropionate/formoterol extra-fine fixed combination in the treatment of asthma: evidence and future perspectives. Expert Opin Pharmacother. 2008;9(3):479-90.

42. Scichilone N. Asthma control: the right inhaler for the right patient. Adv Ther. 2015;32(4):285-92.

43. Usmani OS. Small-airway disease in asthma: pharmacological considerations. Curr Opin Pulm Med. 2015;21(1):55-67.

44. Usmani OS. Small airways dysfunction in asthma: evaluation and management to improve asthma control. Allergy Asthma Immunol Res. 2014;6(5):376-88.
45. Bodzenta-Łukaszyk A, Kokot M. Pharmacological consequences of inhaled drug delivery to small airways in the treatment of asthma. Adv Ther. 2014 31(8):803-16.

46. Corradi M, Chrystyn H, Cosio BG, Pirozynski M, Loukides S, Louis R, Spinola $M$, Usmani OS. NEXThaler, an innovative dry powder inhaler delivering an extrafine fixed combination of beclometasone and formoterol to treat large and small airways in asthma. Expert Opin Drug Deliv. 2014;11(9):1497-506.

47. Popov TA, Petrova D, Kralimarkova TZ, Ivanov Y, Popova T, Peneva M, Odzhakova T, llieva Y, Yakovliev P, Lazarova T, Georgiev O, Hodzhev V Hodzheva E, Staevska MT, Dimitrov VD. Real life clinical study design supporting the effectiveness of extra-fine inhaled beclomethasone/ formoterol at the level of small airways of asthmatics. Pulm Pharmacol Ther. 2013;26(6):624-9.

48. Vos W, De Backer J, Poli G, De Volder A, Ghys L, Van Holsbeke C, Vinchurkar $\mathrm{S}$, De Backer L, De Backer W. Novel functional imaging of changes in small airways of patients treated with extrafine beclomethasone/formoterol. Respiration. 2013;86(5):393-401.

49. Nakaji H, Petrova G, Matsumoto H, Iwata T, Ito I, Oguma T, Inoue H, Tajiri T, Nagasaki T, Kanemitsu Y, Niimi A, Mishima M. Effects of 24-week add-on treatment with ciclesonide and montelukast on small airways inflammation in asthma. Ann Allergy Asthma Immunol. 2013;110(3):198-203.

50. Papi A, Nicolini G, Crimi N, Fabbri L, Olivieri D, Rossi A, Paggiaro P. Stepdown from high dose fixed combination therapy in asthma patients: a randomized controlled trial. Respir Res. 2012;13:54.

51. Scichilone N, Battaglia S, Sorino C, Paglino G, Martino L, Paternò A, Santagata R, Spatafora M, Nicolini G, Bellia V. Effects of extra-fine inhaled beclomethasone/formoterol on both large and small airways in asthma. Allergy. 2010;65(7):897-902.

52. Huchon G, Magnussen H, Chuchalin A, Dymek L, Gonod FB, Bousquet J. Lung function and asthma control with beclomethasone and formoterol in a single inhaler. Respir Med. 2009;103(1):41-9.

53. de Kant KD, van Vliet D, Kester AD, Hendriks HJ, Damoiseaux JG, Wodzig WK, Rijkers GT, Dompeling E, Jöbsis Q. Comparison of the anti-inflammatory effects of extra-fine hydrofluoroalkane-beclomethasone vs fluticasone dry powder inhaler on exhaled inflammatory markers in childhood asthma. Ann Allergy Asthma Immunol. 2008;100(6):601-7.

54. Gillissen A, Richter A, Oster H, Criée CP. Efficacy and safety of once or twice daily inhalation of extrafine HFA beclomethasone dipropionate in patients with mild to moderate asthma. J Physiol Pharmacol. 2007;5(Pt 1):233-41.

55. Menzies D, Nair A, Hopkinson P, McFarlane L, Lipworth BJ. Differential antiinflammatory effects of large and small particle size inhaled corticosteroids in asthma. Allergy. 2007;62(6):661-7.

56. Boulet LP, Cartier A, Ernst P, Larivée P, Laviolette M. Safety and efficacy of HFA-134a beclomethasone dipropionate extra-fine aerosol over six months. Can Respir J. 2004;11(2):123-30.

57. Aubier M, Wettenger R, Gans SJ. Efficacy of HFA-beclomethasone dipropionate extra-fine aerosol (800 microg day $(-1)$ ) versus HFAfluticasone propionate (1000 microg day $(-1))$ in patients with asthma. Respir Med. 2001;95(3):212-20.

58. Magnussen $\mathrm{H}$. Equivalent asthma control after dose reduction with HFA134a -beclomethasone solution aerosol. Comparative Inhaled Steroid Investigation Group (CISIG). Respir Med. 2000;94(6):549-55.

59. Kirsten AM, Watz H, Brindicci C, Piccinno A, Magnussen H. Effects of beclomethason/formoterol and budesonide/formoterol fixed combinations on lung function and airway inflammation in patients with mild to moderate asthma-an exploratory study. Pulm Pharmacol Ther. 2015;31:79-84.

60. Kanniess F, Scuri M, Vezzoli S, Francisco C, Petruzzelli S. Extrafine -beclomethasone/formoterol combination via a dry powder inhaler (NEXThaler $\left({ }^{(}\right)$) or pMDI and beclomethasone Monotherapy for maintenance of asthma control in adult patients: a randomised, double-blind trial. Pulm Pharmacol Ther. 2015;30:121-7.

61. Papi A, Corradi M, Pigeon-Francisco C, Baronio R, Siergiejko Z, Petruzzelli S, Fabbri LM, Rabe KF. Beclometasone-formoterol as maintenance and reliever treatment in patients with asthma: a double-blind, randomised controlled trial. Lancet Respir Med. 2013;1(1):23-31.

62. Paggiaro P, Patel S, Nicolini G, Pradelli L, Zaniolo O, Papi A. Stepping down from high dose fluticasone/salmeterol to extrafine BDP/F in asthma is costeffective. Respir Med. 2013;107(10):1531-7.

63. Barnes N, van Noord JA, Brindicci C, Lindemann L, Varoli G, Perpiña M, Guastalla D, Casula D, Patel S, Chanez P, FACTO (Foster ${ }^{\circledR}$ As Complete 
Treatment Option) Study Group. Stepping-across controlled asthmatic patients to extrafine beclometasone/formoterol combination. Pulm Pharmacol Ther. 2013;26(5):555-61.

64. Terzano C, Cremonesi G, Girbino G, Ingrassia E, Marsico S, Nicolini G, Allegra L, PRISMA (PRospectlve Study on asthMA control) Study Group. 1-year prospective real life monitoring of asthma control and quality of life in Italy. Respir Res. 2012;13:112.

65. Brusselle G, Peché R, Van den Brande P, Verhulst A, Hollanders W, Bruhwyler $J$. Real-life effectiveness of extrafine beclometasone dipropionate/formoterol in adults with persistent asthma according to smoking status. Respir Med. 2012;106(6):811-9.

66. Corda L, Gardenghi GG, Modina D, Montemurro LT, Novali M, Tantucci C. Effects on small airway obstruction of long-term treatments with beclomethasone/formoterol hydrofluoroalkane (metered-dose inhaler) versus fluticasone/salmeterol (dry-powder inhaler) in asthma: a preliminary study. Allergy Asthma Proc. 2011;32(6):29-34.

67. O'Connor BJ, Collarini S, Poli G, Brindicci C, Spinola M, Acerbi D, Barnes PJ, Leaker B. Rapid effects of extrafine beclomethasone dipropionate/ formoterol fixed-combination inhaler on airway inflammation and bronchoconstriction in asthma: a randomised controlled trial. BMC Pulm Med. 2011;21(11):60

68. Singh D, Piccinno A, Borrill Z, Poli G, Acerbi D, Meuleners L, Woodcock A. Tolerability of high cumulative doses of the HFA modulite beclomethasone dipropionate/formoterol combination inhaler in asthmatic patients. Pulm Pharmacol Ther. 2008;21(3):551-7.

69. Papi A, Paggiaro P, Nicolini G, Vignola AM, Fabbri LM, ICAT SE study group Beclomethasone/formoterol vs fluticasone/salmeterol inhaled combination in moderate to severe asthma. Allergy. 2007;62(10):1182-8,

70. Papi A, Paggiaro PL, Nicolini G, Vignola AM, Fabbri LM. Inhaled Combination Asthma Treatment versus SYmbicort (ICAT SY) Study Group Beclomethasone/formoterol versus budesonide/formoterol combination therapy in asthma. Eur Respir J. 2007;29(4):682-9.

71. Molimard M, Martinat Y, Rogeaux Y, Moyse D, Pello JY, Giraud V Improvement of asthma control with beclomethasone extrafine aerosol compared to fluticasone and budesonide. Respir Med. 2005;99(6):770-8.

72. Price D, Thomas M, Haughney J, Lewis RA, Burden A, von Ziegenweidt J, Chisholm A, Hillyer EV, Corrigan CJ. Real-life comparison of beclometasone dipropionate as an extrafine- or larger-particle formulation for asthma. Respir Med. 2013;107(7):987-1000.

73. Martin RJ, Price D, Roche N, Israel E, van Aalderen WM, Grigg J, Postma DS, Guilbert TW, Hillyer EV, Burden A, von Ziegenweidt J, Colice G. Costeffectiveness of initiating extrafine- or standard size-particle inhaled corticosteroid for asthma in two health-care systems: a retrospective matched cohort study. NPJ Prim Care Respir Med. 2014;24:14081.

74. Barnes N, Price D, Colice G, Chisholm A, Dorinsky P, Hillyer EV, Burden A, Lee AJ, Martin RJ, Roche N, von Ziegenweidt J, Israel E. Asthma control with extrafine-particle hydrofluoroalkane-beclometasone vs. large-particle chlorofluorocarbon-beclometasone: a real-world observational study. Clin Exp Allergy. 2011:41(11):1521-32.

75. Allegra L, Cremonesi G, Girbino G, Ingrassia E, Marsico S, Nicolini G, Terzano C, PRISMA (PRospectlve Study on asthMA control) Study Group. Real-life prospective study on asthma control in Italy: cross-sectional phase results. Respir Med. 2012;106(2):205-14.

76. Hogg JC, McDonough JE, Suzuki M. Small airway obstruction in COPD: new insights based on micro-CT imaging and MRI imaging. Chest. 2013;143(5): 1436-43.

77. Hersh CP, Washko GR, Estépar RS, Lutz S, Friedman PJ, Han MK, Hokanson JE, Judy PF, Lynch DA, Make BJ, Marchetti N, Newell Jr JD, Sciurba FC, Crapo $J D$, Silverman EK, COPDGene Investigators. Paired inspiratory-expiratory chest CT scans to assess for small airways disease in COPD. Respir Res. 2013; $14: 42$

78. Stewart Jl, Criner GJ. The small airways in chronic obstructive pulmonary disease: pathology and effects on disease progression and survival. Curr Opin Pulm Med. 2013;19(2):109-15.

79. Martin C, Frija J, Burgel PR. Dysfunctional lung anatomy and small airways degeneration in COPD. Int J Chron Obstruct Pulmon Dis. 2013;8:7-13.

80. Bhatt SP, Soler X, Wang X, Murray S, Anzueto AR, Beaty TH, Boriek AM, Casaburi R, Criner GJ, Diaz AA, Dransfield MT, Curran-Everett D, Galbán CJ, Hoffman EA, Hogg JC, Kazerooni EA, Kim V, Kinney GL, Lagstein A, Lynch DA, Make BJ, Martinez FJ, Ramsdell JW, Reddy R, Ross BD, Rossiter HB, Steiner RM, Strand MJ, van Beek EJ, Wan ES, Washko GR, Wells JM, Wendt
CH, Wise RA, Silverman EK, Crapo JD, Bowler RP, Han MK, COPDGene Investigators. Association between functional small airways disease and FEV1 decline in COPD. Am J Respir Crit Care Med. 2016;194(2):178-84.

81. Pisi R, Aiello M, Zanini A, Tzani P, Paleari D, Marangio E, Spanevello A, Nicolini G, Chetta A. Small airway dysfunction and flow and volume bronchodilator responsiveness in patients with chronic obstructive pulmonary disease. Int J Chron Obstruct Pulmon Dis. 2015;10:1191-7.

82. Hirano T, Matsunaga K, Sugiura H, Minakata Y, Koarai A, Akamatsu K, Ichikawa T, Furukawa K, Ichinose M. Relationship between alveolar nitric oxide concentration in exhaled air and small airway function in COPD. J Breath Res. 2013;7(4):046002.

83. Shukla SD, Muller HK, Latham R, Sohal SS, Walters EH. Platelet-activating factor receptor (PAFr) is upregulated in small airways and alveoli of smokers and COPD patients. Respirology. 2016;21(3):504-10.

84. Ostridge K, Williams N, Kim V, Bennett M, Harden S, Welch L, Bourne S, Coombs NA, Elkington PT, Staples KJ, Wilkinson TM. Relationship between pulmonary matrix metalloproteinases and quantitative $C T$ markers of small airways disease and emphysema in COPD. Thorax. 2016;71(2):126-32.

85. Postma DS, Roche N, Colice G, Israel E, Martin RJ, van Aalderen WM, Grigg J, Burden A, Hillyer EV, von Ziegenweidt J, Gopalan G, Price D. Comparing the effectiveness of small-particle versus large-particle inhaled corticosteroid in COPD. Int J Chron Obstruct Pulmon Dis. 2014:9:1163-86.

86. Scichilone N, Benfante A, Morandi L, Bellini F, Papi A. Impact of extrafine formulations of inhaled corticosteroids/long-acting beta-2 agonist combinations on patient-related outcomes in asthma and COPD. Patient Relat Outcome Meas. 2014;5:153-62.

87. Short PM, Williamson PA, Lipworth BJ. Effects of extra-fine inhaled and oral corticosteroids on alveolar nitric oxide in COPD. Lung. 2012;190(4):395-401.

88. Tzani P, Crisafulli E, Nicolini G, Aiello M, Chetta A, Clini EM, Olivieri D. Effects of beclomethasone/formoterol fixed combination on lung hyperinflation and dyspnea in COPD patients. Int J Chron Obstruct Pulmon Dis. 2011;6:503-9.

89. Siddiqui SH, Guasconi A, Vestbo J, Jones P, Agusti A, Paggiaro P, Wedzicha JA, Singh D. Blood eosinophils: a biomarker of response to extrafine beclomethasone/formoterol in chronic obstructive pulmonary disease. Am J Respir Crit Care Med. 2015;192(4):523-5.

90. Wedzicha JA, Singh D, Vestbo J, Paggiaro PL, Jones PW, Bonnet-Gonod F, Cohuet G, Corradi M, Vezzoli S, Petruzzelli S, Agusti A, FORWARD Investigators. Extrafine beclomethasone/formoterol in severe COPD patients with history of exacerbations. Respir Med. 2014;108(8):1153-62.

91. Singh D, Nicolini G, Bindi E, Corradi M, Guastalla D, Kampschulte J, Pierzchała W, Sayiner A, Szilasi M, Terzano C, Vestbo J, FUTURE (Foster Upgrades TherapeUtic care in REspiratory disease) study group. Extrafine beclomethasone/formoterol compared to fluticasone/salmeterol combination therapy in COPD. BMC Pulm Med. 2014;14:43.

92. Singh D, Kampschulte J, Wedzicha JA, Jones PW, Cohuet G, Corradi M, Higenbottam T, Petruzzelli S, Vestbo J. A trial of beclomethasone/formoterol in COPD using EXACT-PRO to measure exacerbations. Eur Respir J. 2013; 41(1):12-7.

93. Calverley PM, Kuna P, Monsó E, Costantini M, Petruzzelli S, Sergio F, Varoli G, Papi A, Brusasco V. Beclomethasone/formoterol in the management of COPD: a randomised controlled trial. Respir Med. 2010;104(12):1858-68.

94. Cazzola M, Pasqua F, Ferri L, Biscione G, Cardaci V, Matera MG. Rapid onset of bronchodilation with formoterol/beclomethasone Modulite and formoterol/budesonide Turbuhaler as compared to formoterol alone in patients with COPD. Pulm Pharmacol Ther. 2011;24(1):118-22.

\section{Submit your next manuscript to BioMed Central and we will help you at every step:}

- We accept pre-submission inquiries

- Our selector tool helps you to find the most relevant journal

- We provide round the clock customer support

- Convenient online submission

- Thorough peer review

- Inclusion in PubMed and all major indexing services

- Maximum visibility for your research

Submit your manuscript at www.biomedcentral.com/submit
C) Biomed Central 